\title{
Ewa Ciszewska
}

University of Lodz

\section{Film Education in Poland - Historical Outline and Current State of Research}

Even though film education programmes in Poland have been conducted both within and outside formal education, researchers have traditionally treated them as phenomena strongly connected with the schooling system. Additionally, Polish academic texts devoted to film education are mostly prescriptive in character, while only a small number of texts deal with evaluating and summarising the already existing programmes. The lack of evaluation of film education conducted in schools stems from insufficient amount of data, since - as there is no separate school subject devoted to film education and no opportunities to assess students' knowledge - film education in schools has mostly been carried out through isolated projects. Notable exceptions can be found in the works of Bolesław W. Lewicki and Ewelina Nurczyńska-Fidelska, who both created, conducted and evaluated film education programmes, and thus their contributions will feature prominently in the present study. ${ }^{1}$ Secondary literature on the subject also includes a series of texts that could be grouped under the joint title "From My Experiences" (to use the crossheading of a text published in 1975), presenting comments and observations by film education practitioners (Szlązakowa, 1967; Blicharska, 1975).

It is important to signal, however, that film education in Poland is stretched between three separate disciplines: the so-called applied film studies, pedagogy and Polish studies; as a result, articles on film education have been dispersed across a number of periodicals and volumes devoted to those three areas of study. This diffusion of published research is also partly linked to the multiplicity of entities and initiatives focused on film education. Often this is merely a filler class, not necessarily connected with the main profile of a given institution, and materials published afterwards have low print runs and narrow distribution. Taking all this

Presently I will refer to only one volume entitled Edukacja filmowa w szkole podstawowej $i$ średniej [Film Education in Primary and Secondary Schools] (Koblewska, Butkiewicz 1985), including nine texts by Lewicki and Nurczyńska-Fidelska, presenting the findings of the research "A Review of Film

Teaching Techniques in Schools" conducted in 1977-1981. 
complexity into account, the intention behind this paper is to focus on film education from the point of view of academic film studies.

One idea frequently repeated by Polish academics is that film education classes should be conducted in schools by specially trained teachers (mainly Polish language teachers), which has resulted in producing a number of lesson plans for all educational levels. Those lesson plans provide fascinating material for the study of how thinking about film education has evolved in Poland over the years. The changes of approach can be observed in teaching materials, techniques and also in the very subject of film education. ${ }^{2}$

The lesson plans are usually prepared by pedagogists and Polish language teachers and are often collected in volumes after various contests (see e.g. initiatives launched by Polonistyka [Polish Studies periodical] [Frycie, Koblewska, 1979] and the Central Cabinet for Film Education). ${ }^{3}$ Primary sources - such as lesson plans, educational programme descriptions and materials prepared by the organisers (Filmoteka Szkolna [Film Library], Nowe Horyzonty Edukacji Filmowej [New Horizons of Film Education], Akademia Filmu Polskiego [Polish Film Academy] and KinoSzkoła [CinemaSchool], to name but the most recent few) vastly outnumber secondary sources that could provide evaluation of the implementation of such initiatives.

This is not to say, however, that film education remains a tabula rasa of Polish academic publishing. Throughout the years, a number of texts on the subject have been published. It is also possible to distinguish recurring motifs in texts representing various periods of film education research, such as technological issues or teacher training. Another branch of study in this field is represented by research into film reception by children and teenagers (see e.g. invaluable texts by Adam Kulik, 1964; or Janina Koblewska-Wróblowa, 1961).

Film education as a field of study saw its peak in Poland in the 1960s and 1970s. Most of the texts which are discussed here were published or translated

\footnotetext{
2 See e.g. Nurczyńska-Fidelska, Parniewska, Ulińska, 1984; Koblewska, Butkiewicz, 1985 (the second part of the volume includes 58 lesson plans focused on film education); Marzec, 1990; Nurczyńska-Fidelska, Parniewska, Popiel-Popiołek, Ulińska, 1993; Hendrykowski, 1997 (including 26 suggested lesson plans; contrary to the title of the volume, these were prepared not only by Polish scholars but also by film and literary scholars). Nowadays, most teachers access lesson plans online through databases such as Edukacjafilmowa.pl or Filmotekaszkolna.pl. Increasingly often film distributors commission lesson plans for their films and make them available online. See educational files for films such as Hiszpanka [Influenza] (2014, dir. Łukasz Barczyk) (Kinonh.pl); Jack Strong (2014, dir. Władysław Pasikowski) (Stylowy.net).

3 Since 2008, the Central Cabinet for Film Education (Centralny Gabinet Edukacji Filmowej, CGEF) publishes volumes in the series titled Zoom. Cinema in Close-Up, including various methodological and interpretative ideas in the form of lesson plans. The first volume, comprising 17 lesson plans, accompanied the CGEF project "Film Duels 4", carried out in 2008. Subsequent volumes accompanied the Polish Film Study Conferences in Borki (held in Radziejowice since 2011) and distributed among the participants free of charge. By 2015, six volumes in total had been published; since 2011 all materials have also been posted online at Edukacjafilmowa.pl. Since 2012, lesson plans collected by the series' editors have also competed in a contest for the best lesson plan.
} 
in this exact period. This trend coincided with a global shift to incorporate films in school education - either as a separate school subject or as a number of activities spread across several existing subjects. ${ }^{4}$ This coincided with several UNESCO reports ${ }^{5}-$ known in Poland and frequently cited in Polish articles on the subject - and UNESCO conference materials. The international lobby for film education in the 1960s and $1970 s^{6}$ offers an interesting parallel with the present-day situation, where EU funds allow various bodies to finance theoretical papers as well as programmes in film education, and to facilitate audience building.

\section{On Film and School: A “Call for Organised Action” (Lewicki, 1995, p. 366)}

Strong links between film and formal education that seem to have dominated Polish academic discourse on the subject can be explained through widespread discussion regarding the persuasive power of audiovisual media that predestine them to perform educational tasks (especially in the light of socialist education) ${ }^{8}$ as well as specific postulates concerning formal education that was supposed to prepare young people for analytical, conscious reception of works of art, including films. "Just as we supervise our students' contact with literature and music, so we need to introduce them to films", wrote Bolesław W. Lewicki in his Mtodziez przed ekranem [Young People in front of Screens] (1995, p. 357). "School needs to guide young people towards good films, works of high artistic quality. The responsibility for this lies in the hands of Polish language teachers, if only because of the prominent status they enjoy in our schools" (Lewicki, 1995, p. 359). In Czech

${ }^{4}$ For descriptions of former and current educational models see Witold Bobiński (2001, pp. 59-71) and Janina Koblewska (1976, pp. 31-78).

5 Janina Koblewska quotes, among others, a work by Jan Maria Lambert Peters titled Teaching about Film, commissioned by UNESCO in 1961 (a translation of this document from French was published in Poland in 1965) and his Learning to Be. The World of Education Today and Tomorrow, published in 1972 in London.

${ }^{6}$ As Zoë Druick points out, film education played a role in UNESCO educational projects aimed at promoting world peace through free flow of information (which meant fighting against illiteracy, including media illiteracy) and modernisation (with special focus on instructional and educational films). At the same time, the author exposes the utilitarianism of UNESCO programmes, which had become an instrument of propagating US geopolitical dominance (Druick, 2011, pp. 81-102).

7 See Górecki, Sotomska, 2014. This pamphlet was published in 2014 thanks to financial support from the Creative Europe MEDIA Programme (the publishers were programme offices in BerlinBrandenburg, Denmark and Poland). It comprises a list of initiatives in film education implemented in 23 European countries (including Poland). See A Framework for Film Education in Europe (2015) and reports published on the website Koalicjafilmowa.pl produced with the objective of providing a common point of reference for film education specialists all across Europe (for designing, managing and evaluating film education projects). Postulates and guidelines outlined in this work are not normative in character; they were compiled by a team of 25 scholars, film education specialists, NGOs and government body representatives from 20 countries (including Poland).

8 First comments on film's influence on the younger generation appeared as early as in 1913 (see Ludwik Skoczylas, 1975, pp. 77-82). The new cultural phenomenon and its educational potential were also discussed by Jan Stanisław Bystroń, Jan Kraskowski, Jerzy Toeplitz and Leopold Blaustein. See Bobiński, 2001, pp. 71-77. 
Republic, Petr Denk, who similarly to Lewicki linked film to school education, pointed to two separate functions of films to be explored in schools: firstly, their utility in transmitting educational content; secondly, their potential as a separate field of study (Denk, 1936). The aim of film education at the time was to "replace unhealthy cinema addiction with a correct approach to films" (Lewicki, 1996, p. 361). It should be noted, therefore, that the main objective of film education was different from what it is today - let us only compare it with Filmoteka Szkolna, the flagship educational project of the Polish Film Institute, whose aim is to promote the canon of independent cinema and celebrate its achievements. Lewicki criticised any cult of directors and actors. "School needs to overcome the drug-like appeal of the silver screen", he pronounced (Lewicki, 1935, p. 364), calling for film education whose chief objective would be to make students more film-conscious. This goal was to be achieved through transmitting "film reading" skills and offering a careful selection of film works presented to students, especially those with educational content.

Many teachers and film education specialists embraced the concept of incorporating film in the process of aesthetic education. This approach was represented by the educationalist Henryk Depta, who called for developing theories and methods for film use in education:

It seems that within the scope of aesthetic education films above all should enjoy a special, privileged position. Why so? Because this form of art is ubiquitous in the life of modern man; needless to say it should be given a similar role in their education (Depta, 1975, p. 18).?

Depta distinguished between film education and education through film, and he clearly favoured the latter: "Film education is a necessary condition of proper education through film; but film education can only be justified as far as it serves education through film" (Depta, 1975, pp. 22-26). The role of films as tools of aesthetic education is still visible today, especially in projects addressed at the youngest viewers, such as the Kids Film Festival organised since 2014 by the New Horizons Association (Stowarzyszenie Nowe Horyzonty), and has been reflected in a series of meetings and debates devoted to this issue.

For Bolesław W. Lewicki, film education in schools could only be possible as "organised action" coordinated by school authorities, universities and teachers. $\mathrm{He}$ encouraged Polish language teachers to monitor their students' film experiences, organise group outings to watch films and educate their students in terms of film language and history. He also recommended that school authorities organise special screenings of film masterpieces paired with lectures; universities, he argued, should in turn provide special courses for future teachers (especially Polish language teachers). "Rationalising young people's attitudes towards films is part of a school's duties. We only need to begin", he wrote (Lewicki, 1935, p. 366).

\footnotetext{
9 See Depta, 1983.
} 
Lewicki was both a theoretician and a practitioner; while he worked in Lviv, he organised courses and training sessions for teachers. As it happens, such a situation is typical among academics, for seldom has theoretical reflection appeared without previous practical experience, be it in schools or in creating and implementing extracurricular educational programmes. The same dualism can be observed in the biography of Ewelina Nurczyńska-Fidelska, who - many years before any theoretical works on film education appeared - got to know the reality of the Polish educational system working first in a primary school, and subsequently in Secondary School no. 19 in Łódź (Klejsa, 2016). After she moved on to becoming an academic, she transformed her teaching interests into a field of research. Incorporating films into school curriculum as well as exploring their educational utility became a lifelong project for her. She pursued her academic work through various experimental and implementation tasks followed by scientific commentary and evaluation..$^{10}$ She also devoted much time to participating in the works of various bodies, discussing and initiating programmes aimed at reinforcing the role of films in school education. ${ }^{11}$

Despite many efforts on the part of academia and Polish teachers, film education did not obtain the status of being a separate school subject in the 1970s and 1980s. ${ }^{12}$ As a member of the Curriculum Board of the Ministry of Education, Nurczyńska-Fidelska participated in the work on the 1980s school curriculum reform. As a result, the official curriculum of 1984 for primary and secondary schools included an unprecedented (and ever since then unrivalled) number of film elements. In the end, neither the programme, nor its premises outlined in the book Edukacja filmowa na tle kultury literackiej [Film Education in the Light of Literary Culture] (1989) and the collective volume Film w szkolnej edukacji humanistycznej [Film in School Education in Humanities] (1993) have ever been implemented; ${ }^{13}$

\footnotetext{
${ }^{10}$ Nurczyńska-Fidelska's research, financed by the Ministry of Education, which she herself described as "a participant experiment" (consisting of designing film education methods and their subsequent evaluation), resulted in a number of inspiring works. The findings of experimental-implementation research conducted in 1977-1979 in the Chair for Literary Theory at the University of Lodz (as part of the Ministry of Education programme "A Review of Film Teaching Techniques in Schools") were published in a volume titled Edukacja filmowa w szkole podstawowej i średniej [Films in Primary and Secondary Education] (Koblewska, Butkiewicz, 1985). The findings of the research conducted in 1986-1990 provided material for the works Edukacja filmowa na tle kultury literackiej [Education in the Light of Literary Culture] (which earned Nurczyńska-Fidelska a post-doctoral degree from the University of Wroclaw in 1989) and Film w szkolnej edukacji humanistycznej [Film in School Education in Humanities] (1993).

${ }^{11}$ In 1975-1984, Nurczyńska-Fidelska was a member of the School Curriculum Institute in the Ministry of Education, which provided her with opportunities to influence the content of Polish language classes. In the 1980s, she was also a member of the Curriculum Board at the National Arts Centre for Children and Youths in Poznań, which was at that time a very active and influential institution.

${ }_{12}$ Postulates for public film education published in the 1960s and 1970s in journals such as Nowa Szkota [New School], Polonistyka [Polish Studies], Kino, [Cinema], Kamera [Camera], as well as brought up in meetings held during the International Festival of Film Debuts in Koszalin, as quoted by Zbigniew Korsak (2004, pp. 117-134).

${ }^{13}$ For more on film as a subject of school education in Poland, see Bobiński, 2001, pp. 71-89.
} 
nevertheless, we should appreciate the scale of the project and its original perspective. The programme suggested that films should be treated as both a form of art and an element of mass culture; hence, "Film education should prepare young people for conscious and critical reception of films, and for this reason it should be focused on artistic experience and broadening the students' knowledge about film. The teachers need to present unique features of film, its special language and tropes, their function and the links between film and other art forms" (Primary school curriculum for Polish language, $4^{\text {th }}-8^{\text {th }}$ grade, 1985 , p. 40). ${ }^{14}$

The process of introducing film in schools has still not been successfully completed. On the contrary, after 1990 it is possible to trace a tendency to gradually remove film and audiovisual media from Polish language classes. At the same time, the educational reform of 1999 introduced supplementary educational threads, including a media thread (subsequently criticised for its allegedly fetishist approach to technology and its elimination of aesthetic education content) (Nurczyńska-Fidelska, 2002, p. 456). In the 2002/2003 school year, the list of subjects taught in upper-secondary schools - general, specialised and technical was extended to incorporate cultural studies (one lesson per week for one school year) whose curriculum obliged teachers to include film education (though it did not provide any specific guidelines). In reality, the subject was mostly devoted to visual arts, with only minor references to films (Moraczewski, 2003, p. 88). In his discussion on the role of films in the national curriculum after 2009, Witold Bobiński points out that "the curriculum is so clear and specific that it prevents teachers from omitting film education elements in the course of Polish language classes. At the same time, the guidelines are general enough to allow teachers to decide the extent and form of that education on an individual basis" (Bobiński, 2001, p. 100). Simultaneously, Bobiński offers his own strategy of using films for teaching literature (Bobiński, 2001, pp. 151-331).

\section{Technological and Organisational Constraints of Film Education in Schools}

Efforts required to make sure that it [the equipment - author's note] functions properly [...] redirect teachers' and students' attention to technical issues. Minutes are passing, while the whole group struggles to make the equipment work; screwdrivers are used and the most skilled among the students have a chance to show off; finally, with their help, the device is repaired. Seemingly, the lesson is back on track but in fact a great number of students begin to ponder a question unintended by their teacher what happened to this particular part of the tape recorder that it should snap like that? (Polakowski, 1967, p. 232).

\footnotetext{
${ }^{14}$ Quoted in Bobiński, 2001, p. 83.
} 
The quote above, taken from a 1967 work Środki techniczne w nauczaniu jezzyka polskiego $w$ szkole średniej [Technical Equipment in Teaching Polish Language in Secondary Schools] edited by Alicja Szlązakowa, presents an issue which - in spite of technological progress, or perhaps as a result of that progress - has remained problematic until the present day, namely: how to cope with technology interfering with the lesson. Many film scholars know all too well how often one needs to struggle with a projector, agonise to open a Power Point presentation saved in a format that cannot be read by the software installed on a university computer, or embark on a quest to discover the right plug. Then there is also searching for an HDMI socket and groping for a power supply, not to mention problems with switching between various sources for different film fragments. It goes without saying, therefore, that teachers using film in the classroom need not only have a thorough knowledge of their subject but also be skilled in using all sorts of equipment - and this surely requires time and effort, especially if one needs to use several different devices.

Szlązakowa's work (mentioned above) stems from reflection on the issue which nowadays is seldom directly addressed: what are the advantages but also the problems of using multimedia in schools? ${ }^{15}$ While analysing the use of devices such as a radio, tape recorder, slide viewer, television set or film projector, teachers appreciate the appeal of new media but at the same time they remain conscious of various traps linked with using audio-visual materials in class. Among the most common problems they listed was the use of various devices simply as transmitters of content, without paying sufficient attention to the specific aesthetic of a given medium and the process of creating the work. Additionally, they stressed organisational and technological problems connected with the use of new media that tend to impact on the teaching process, distracting students' attention from the topic and drawing it to technological issues. Jan Polakowski also wrote about the tendency to fetishize audiovisual teaching resources, which results in students' passivity and deprives teachers of the opportunity to exert their influence (Polakowski, 1967, p. 226), while Ewelina Nurczyńska-Fidelska suggested switching the equipment on before class, as usually the process of making it work consumes too much valuable time (Nurczyńska-Fidelska, 1967, p. 161).

Another important issue addressed by scholars researching film education in schools was the practical side of organising workshops of Polish language teachers using films in their classes. How to obtain materials? And how to present them? In 1967, Janusz Plisiecki described his experience of teaching film at school in such a way:

The conditions are reasonably good; I am teaching in a room with a screen.

Still, I have experienced numerous difficulties:

- the school owns two projectors but both can only work with $16 \mathrm{~mm}$ film tapes, while some films about art (e.g. miniatures of The Balthasar

15 The volume also includes a bibliography of works devoted to technology used in schools: Bibliografia pomocnicza dla nauczycieli, compiled by Szlązakowa, 1967, p. 243-244. 
Behem Codex) have $35 \mathrm{~mm}$ copies in full colour but only black-andwhite copies in $16 \mathrm{~mm}$, which means that I have to give up the colour version and use the black-and-white one instead;

- $\quad$ some film tapes are so damaged that they hardly produce the right effect; in fact, these should be withdrawn from use;

- $\quad$ some films include too much written or spoken content, which makes it difficult to set up problems for discussion;

- the local "Filmos"16 does not possess all films included in the catalogues or announced in Kamera [Camera] monthly; additionally, they are not always able to provide films for teachers on request, so it seems advisable for schools to own copies of the most valuable and frequently used films;

- $\quad$ screening speed is such that some more difficult moments should be replayed but as our films have no spiral wrapping, the tape cannot be rotated;

- $\quad$ the last twenty years or so have supplied us with over a hundred films about art, but this is still very few in comparison with our needs (Plisiecki, 1967, pp. 221-222).

Many of the problems listed by Plisiecki are now outdated, for instance damaged copies (it's hard to imagine anyone would use $8 \mathrm{~mm}, 16 \mathrm{~mm}$ or $35 \mathrm{~mm}$ film projectors nowadays except for the sake of demonstration) or impossibility of working with selected fragments (modern software provides options such as pausing, repetition, speeding up, jumping to another section, etc.). Meanwhile, new issues have arisen, such as film piracy and copyright problems. Still, most of these $1960 \mathrm{~s}$ problems remain valid today: the availability of films for schools, the role ascribed to film education in the curriculum, the availability of equipment and the quality of films themselves.

Organisational and financial problems of obtaining films for school use from state distributors inspired scholars and practitioners (including Plisiecki) to call for the creation of school repositories. Several attempts to establish those were made before the war: in 1935/1936 the Film Institute of the Polish Telegraph Agency in cooperation with the Ministry of Religions and Public Education compiled a list of films to be used in schools. Simultaneously, steps were taken to equip educational institutions, and later also schools, with $8 \mathrm{~mm}$ and $16 \mathrm{~mm}$ film projectors. In 1967, Ewelina Nurczyńska-Fidelska called for the creation of an easily accessible film collection for schools: "Until we have a film library storing all films that are useful in

16 The "Filmos" Educational Film Centre was a two-tier institution, operating on a national and regional level. Its chief purpose was the distribution of short films in cinemas, local cultural centres, schools and private flats via its regional offices. In 1974, the "Filmos" was merged with the Film Rental Centre, creating the Film Distribution Centre. In 1957-1972, "Filmos" published a journal, Kamera [Camera], while the Film Rental Centre released a different one, Studio, in 1973-1975. 
school education and put this library in the hands of an efficient institution which will make those films available (at a reasonable price) for interested teachers, all our efforts to use films in schools remain but a form of educational guerrilla war" (Nurczyńska-Fidelska, 1967, p. 182).

The idea to create film libraries seems to represent all the crucial issues connected with film education in schools, giving priority to its political, ideological and economical aspects. The answers to questions such as which film format should be used (16 mm or $35 \mathrm{~mm}$ ), which films to choose (school/educational or feature films), where they should be produced (in Poland or abroad) and where they should be shown (in a classroom or outside of it) revealed the basic conflict concerning the beneficiaries of film education. Like in Czechoslovakia in 1930s, most interested parties agreed that film education in school should rely on domestic production rather than foreign works. As a result, both in Poland and in Czechoslovakia, film education was incorporated into national film industries: orders for school films accounted for a major part of the income of the Educational Film Studio in Łódź in the 1970s and 1980s. Among the propagators of the idea to use educational films (rather than feature films) in schools was Bolesław W. Lewicki: "Watching educational films teaches one to focus and carefully trace movement on screen; it is similar to learning close, attentive reading. In addition to that, such films expand students' observations and knowledge. Providing educational films, therefore, is among the first responsibilities of a film teacher" (Lewicki, 1995, p. 360). At the same time, it can be stated that the market potential inherent in film education in schools was never recognised in full in communist Poland. The dominant practice became to use short films (school and educational). The presence of feature films (as well as documentaries and cartoons) only changed in 2008, when Filmoteka Szkolna [Film Library] was created, as a joint venture between the Ministry of Culture and National Heritage and the Polish Film Institute (with the aid of Ewelina Nurczyńska-Fidelska).

\section{The Subject of Film Education}

The insufficient number of films addressed at children and teenagers is one of the impeding factors in film education. The lack of new Polish productions addressed at children and teenagers translates directly into their absence in educational programmes, both conducted in schools (such as Filmoteka Szkolna) and outside them. In recent years steps have been taken to encourage the production and distribution of films for younger viewers, promote the issue within the industry and educate both artists and viewers on this aspect. These include, for instance, promoting films for children on the Polish Digital Cinemas Network as part of the domestic productions quota and closer cooperation between the Polish Film Institute and the Ministry of Education to ensure automatic patronage for films addressed at children co-financed by the Institute (Grawon-Jaksik, Materska-Samek, 2016, pp. 69-70). 
Initiatives aimed at popularising films for children and propagating their use in film education have so far taken the form of isolated actions, and they have only reached large cities such as Warsaw and Wroclaw (such as in the case of the Education Department of the New Horizons Association). ${ }^{17}$ Characteristically, most films used in educational projects for early childhood care, primary schools and lower-secondary schools are foreign films (both actor and cartoon). The cinema education project aKINO (October-December 2016) did not include any Polish productions; instead, the organisers used German, French, Italian and Danish films included in the catalogue of the New Horizons Association.

The dominant - and this is the case not only in Poland - paradigm of incorporating film education into national language classes translates into prioritising one specific genre: film adaptations of literary works. Showing these films in class allows teachers to kill two birds with one stone: on the one hand, they can discuss a literary work, while on the other - incorporate elements of working with another medium. This tendency is reflected in teaching materials available for teachers, which tend to prioritise the issue of adaptation. ${ }^{18}$

\section{Competence of Staff Responsible for Film Education}

Well-equipped classrooms, great films and sufficient time for screening them would still not be enough without competent and enthusiastic teachers. Propagators of film education were always conscious of the crucial role of teachers in the process. Basic training sessions and supplementary classes for teachers took many forms before and after World War II, such as courses, workshops and lectures. The most significant step was taken when elements of film studies were incorporated into the Core Curriculum for future Polish language teachers. This became possible thanks to the creation of the Department of Film Studies within the Chair of Literary Theory at the University of Lodz - the first academic unit of its kind in Poland - in 1960. Initially, the Department of Film Studies offered an MA programme focused on film within Polish studies, but in 1975 it became part of cultural studies instead. Film education was occasionally part of Polish scholars' academic education, and it was seldom taught as a separate academic subject within film studies. One consequence of this formal division between Polish studies and film studies - which is still felt today - is the issue of teaching qualifications: graduates of Polish studies usually obtain a license to teach at state schools, while graduates of film studies do not. As a result, film studies spe-

\footnotetext{
17 Other programmes include: Kids Film Festival, Dzieciaki na Horyzoncie [Kids on the Horizon] children's film distribution; W-F Akademii Nowe Horyzonty [P.E. of the New Horizons Academy] film workshops for teachers and educators; "O filmie się rozmawia" [We Talk About Films] - a cycle of psychological workshops for children and parents (Warsaw and Wroclaw); Wychowanie w kinie [Education in the Cinema] - meetings for teachers in Wroclaw and in Warsaw; Film for Kids. Pro a programme devoted to teaching scriptwriting to children.

18 See Nurczyńska-Fidelska, Parniewska, Popiel-Popiołek, Ulińska, 1993. In this volume, the section with lesson plans opens with a chapter titled Film Adaptations of Literary Works as an Example of Adapting Original Texts.
} 
cialists are not entitled to teach in state schools unless they complete additional training and courses.

One way to deal with the effects of this gradual parting of ways between film studies and Polish studies within academia was the creation of the Central Cabinet for Film Education as a joint venture between the Ministry of Culture and Ministry of Education. The initial idea came from Bolesław W. Lewicki and Ewelina Nurczyńska-Fidelska. The chief objective of the Central Cabinet for Film Education, whose $30^{\text {th }}$ anniversary was celebrated in 2015, was to provide support for all school teachers interested in film education. Established in 1985, the Cabinet has been managed by Ewa Kanownik, MA, a graduate of film studies at the University of Lodz. It deals with film education for children and teenagers in school and outside school as well as with providing suitable training for teachers. Its activity is therefore twofold: on the one hand, it organises seminars, training sessions and methodological workshops for teachers and other educators; on the other hand, it offers (free of charge) film classes for students in many Polish schools. ${ }^{19}$

Integrating the milieus of film scholars and school teachers using films for teaching purposes remains an important challenge for all bodies and individuals involved in film education. This aim may be achieved, among other initiatives, through the National Film Conference (organised yearly since 1991; $1^{\text {st }}$ in Borki and since 2011 - at the Ministry of Culture and National Heritage Retreat in Radziejowice). Initiated by the Central Cabinet for Film Education, the conference is a unique event in Poland, as it is directed specifically at teachers and educators using films as educational tools in their teaching practice. ${ }^{20}$ Its Scientific Committee was led by Professor Ewelina Nurczyńska-Fidelska and year after year, among the participants were scholars from the leading departments of film studies in Poland. Panels dedicated to film history are offered beside panels for teachers, who discuss their methodological problems; there are also meetings with film artists and actors from Poland and abroad. The conference is paired with publishing activities which have resulted in the publication of methodological compilations (lesson plans) as well as volumes collecting lectures and papers presented during the event. ${ }^{21}$ The newest initiative aimed at integrating film scholars and teachers is a 5-month pilot project titled "Travelling Film Specialists of the Film Library" (Wędrujący Filmoznawcy Filmoteki Szkolnej) launched by the Polish Film Institute in 2016. Its goal is to offer specialist support for teachers using films as educational tools. The project unites 15 film scholars, Film Library leaders and teachers belonging to local unions in a joint effort to produce ideas for classes (Filmoteka Szkolna, 2016).

${ }^{19}$ More on the activities undertaken by the Cabinet in Ciszewska, 2016, pp. 54-55.

${ }^{20}$ Direct reports from the conference published in a journal Nowa Szkota [New School] have been reprinted in volume form, see Świderska-Chorąży, 2011.

${ }^{21} 5$ volumes were published in 1993-1998 and one more in 2005. In 2015, an anniversary volume was released, containing a selection of papers (Zespół Centralnego Gabinetu Edukacji Filmowej w Łodzi, 2015). Since 2015, archive papers have also been published on Edukacjafilmowa.pl. 


\section{Extracurricular Film Education}

Focused on the links between film and school, the above narrative may suggest that all film education in Poland has been taking place within schools - which is hardly true. In contrast with countries where film education was incorporated into native language classes as early as in the 1960s (as in Czechoslovakia, Hungary and Great Britain), in Poland (and similarly in the USSR, France and Austria) for a long time, film education was conducted largely outside schools, mainly through special film clubs. In fact, Polish solutions were praised abroad for their diversity and catering to the needs of various groups (Trebišovský, Lehuta, Hapala, Zachar, 1969, pp. 21-24).

Since the late 1950s, the main initiators of film education outside schools in communist Poland were independent cinemas and film discussion clubs. Among the leaders of these initiatives was Bolesław W. Lewicki, already mentioned here several times. Lewicki became the chairman of the Coordinating Board of Independent Cinemas, a social body established for supervising cinemas. "This was proper film education, though not institutionalised", wrote Witold Bobiński (2001, p. 12). The process was undoubtedly facilitated by the great artistic shape of the Polish cinema of the period and its enthusiastic reception - films tackled topics important for the viewers, who felt encouraged to participate in heated debates. Film discussion clubs united students, young workers, adults and senior citizens; as a result, film education activities conducted in such groups met the conditions of lifelong learning promoted in Europe today. ${ }^{22}$ Independent cinemas and film discussion clubs also had special tools dedicated to working with teenagers and children, i.e. groups supposedly covered by film education in schools. Since 1960, The Film Discussion Clubs Federation had a special youth committee whose task was to develop concepts for children's and teenagers' film discussion clubs and aid teachers interested in opening them. In 1960, the Federation organised its first seminar for teachers (Koblewska-Wróblowa, 1964, pp. 60-61). Such youth film discussion clubs really existed, as can be proven by Janusz Plisiecki's report of his two-year experience working in such a club operating at Chemistry Technical Secondary School no. 1 in Lublin (Plisiecki, 1976, pp. 97-126). Interestingly, the typical pattern of film discussion clubs (lecture - screening - discussion) remains to this day the most popular model used in film education. Film discussion clubs and independent cinemas continue to participate in educational projects (Silwon-Bublej, 2014, p. 18), although their impact and number have decreased in comparison with their situation in communist Poland. Extracurricular film education in communist Poland was also held in cinemas (both stationary and travelling [Jajko, 2016, pp. 61-68]), at workplaces, in the army, in educational institutions and local cultural centres (Miller, 1980, pp. 111-117; Machwitz, 2007). A wide educational project titled "Getting on with Films" (Z Filmem na Ty), organised by the Federation of Polish

\footnotetext{
22 The aim of film education is "to inspire and equip people across Europe to be able to enjoy, understand, create, explore and share film in all its forms throughout their lives" (A Framework for Film Education in Europe, 2015, p. 3).
} 
Socialist Youth Unions (Federacja Związków Socjalistycznej Młodzieży Polskiej) was offered to young people who combined work and study. Unfortunately, however, these initiatives have not been the subject of sufficient research.

Present-day extracurricular initiatives - such as KinoSzkoła [CinemaSchool], New Horizons of Film Education and individual cinema programmes (such as a project launched by Amok cinema in Gliwice) - are usually meant to supplement school activities and are based on close cooperation with cinemas or other institutions possessing suitable screening rooms. They receive funding from various sources, including the Polish Film Institute, which allows organisers to introduce fees lower than regular ticket prices. Some projects operate on a national scale, such as the New Horizons of Film Education (Nowe Horyzonty Edukacji Filmowej, NHEF) (the flagship project of the New Horizons Association, run since 2005) or the 6-month film education project directed at schools and early childhood care institutions aKino (started in 2016). For the most part, however, initiatives are undertaken in selected institutions, predominantly in large cities. According to the data collected by the organisers, in 201540 cities participated in the NHEF, while 10 cinemas took part in the aKINO project (including Warsaw and Wroclaw, data from October 2016). In the 2015/2016 school year, the activities of the $5^{\text {th }}$ edition of KinoSzkoła [CinemaSchool] were organised in 52 venues (cinemas and local cultural centres) across 11 voivodeships; most of these venues were located in towns with fewer than 100,000 inhabitants. Film education projects run by local cultural centres have met with much interest, provided they are linked to the school curriculum. There are also many informal groups (Barczyk, Wierzejska), associations and foundations involved in film education - which can be confirmed by the long list of members of the Coalition for Cinema Education (Koalicja na Rzecz Edukacji Filmowej) (Koalicjafilmowa.pl).

\section{Conclusion}

The introduction of new media, such as television, video players, computers and mobile phones, as well as data storage devices and media (videotapes, CDs, DVDs and online databases) has imprinted its mark on the discussion on film education. Every new medium seemed to offer a vast spectrum of new possibilities for schools. Nevertheless, ambitious projects to use television ${ }^{23}$ and videotapes in film education (or, broader still, aesthetic education) were often confronted with equipment shortage, lack of necessary infrastructure and randomness of initiatives. As Anikó Imre points out, the educational merit of television was appreciated in all socialist countries (Imre, 2016, pp. 40-65). One of the initiatives conducted in Poland involved the introduction of "telly-lessons" in the early 1980s, which consisted of group watching of selected television programmes. Interested teachers could rely on information concerning television programmes published in the daily press, as well as posters and

${ }^{23}$ Prospects for using television in school education were discussed by Janusz Gajda, see Gajda, 1979; 1982. 
the pamphlet TV program dla szkót [TV Programme for Schools]. "Telly-lessons" turned out to be a failure, however. They were criticised for information overload, but their greatest drawback seemed to be organisational and technological problems that could be blamed partly on schools themselves and partly on the broadcaster. Insufficient equipment (many schools lacked colour television sets), frequent malfunctions and shortage of video players and video tapes can be listed as the most frequent issues related to equipment. Then there were also difficulties with adjusting lesson hours to the television schedule, necessity for frequent changes in the schedule, commuting, and lack of proper rooms at schools. The ambitious idea of using television for educational purposes failed when confronted with the reality of Polish schools. Yet another issue was the attitude of the broadcaster, not sufficiently committed to creating a broader offer of educational broadcasts (Gajda, 1987, pp. 88-97).

A good example of using video tapes in schools can be found in the cycle called "Video Library of Aesthetic Education for Children and Teenagers" (Wideoteka Wychowania Estetycznego Dzieci i Młodzieży) published in the early 1990s by the Documentary and Feature Film Studios under commission from the Ministry of Culture. Unfortunately, the project was discontinued. It seems that what got in the way of these new educational tools was the fast rate of technological progress: television was soon replaced by video tapes, which were soon replaced by CDs and DVDs, which in turn surrendered to online databases. Wide internet access after 2009 (in that year, 13.5\% Polish citizens had access to broadband internet and the number kept growing steadily) as well as the tendency among young people to favour this sphere of audiovisual culture led to a change in the Filmoteka Szkolna [Film Library] project: its $2^{\text {nd }}$ edition (in 2013) was not released on DVD but posted in an online repository instead.

The technological progress linked to the presence of new tools and data storage media as well as new content spread through these new channels (transmedia storytelling, interactive projects, new-generation television series and vlogs) brought the need to redefine the role and place of media (including film) in school education. On the one hand, there have been some attempts to integrate new issues into film education programmes (see educational materials available on Edukacjafilmowa.pl, devoted to topics such as TV series or transmedia storytelling). On the other hand, some voices have called for the creation of a new school subject - media education, digital education or audiovisual education - that would also cover, among other issues, film education (such a model is in force, for instance, in Hungary, where film education is part of media education; Drzewiecki, 2012).

The educational reform of 1999 introduced special educational threads - one such thread was a "media thread" but its elements were seldom incorporated into various school subjects. Media education ceased to be a part of this educational thread in 2008. For a number of years now, there exists a lobby for the project of Fundacja Nowoczesna Polska [Modern Poland Foundation] that offers a broad and interdisciplinary approach to media education, in which IT skills are paired with cultural and civil competences. 
A range of new problems for film education results from the clash between the reality experienced by students - who tend to be media literate and rely on consuming audiovisual content on a daily basis - and the one represented by the school curriculum and teachers' competence. This issue became evident as early as at the beginning of the 1990s: discussing the findings of her research (largely based on material from the late 1970s and the early 1980s, Ewelina Nurczyńska-Fidelska introduced concepts such as "classical model of film education" and the "sum of experience of the generation of teachers that started film education for children and teenagers in Poland" and urged younger generations of teachers to take part in the discussion (Nurczyńska-Fidelska, Batko, 1996, pp. 136-137). It seems, however, that her plea was not heard - or at least not to an extent that would allow reaching any certain conclusions.

Eight years have passed since Filmoteka Szkolna [Film Library] was launched (in 2012 a second film set was created - this time only available online ). The initiative has certainly exerted a considerable impact on the role ascribed to film in school education. It seems then worth asking what are the outcomes of this project and what is its present and future shape. ${ }^{24}$ Some issues that need to be addressed include: the selection of films, the availability of educational material and target participants - in the times when two- and three-year-olds are regular consumers of audiovisual content, maybe it is worth thinking about ways of working with early childhood care pupils, as well as primary and lower-secondary school students. Another area that begs further research is extracurricular film education - both historical (in communist Poland) and present. A large number of programmes, both commercial and non-commercial, deserve closer study.

At present, film education is included in the core programme of a number of organisations, including the National Film Archive (the operator of the Network of Independent and Local Cinemas), ${ }^{25}$ the Film Museum in Lodz, the National Centre of Film Culture (Narodowe Centrum Kultury Filmowej) in Lodz, the Central Cabinet for Film Education in Lodz as well as film units and film studios, such as Documentary Film Studio in Warsaw. This interspersing of competences results in a multiplicity and diversity of projects, which in turn bring frequent incompatibility and unnecessary competition. Individuals eager to become involved in film education have to face a difficult dilemma: which institutional body should be chiefly responsible for film education in Poland, where to find reliable information on the subject and what are the main objectives for the nearest future.

\footnotetext{
${ }^{24}$ Partial attempt at an evaluation of the Filmoteka Szkolna project can be found in a report made on the basis of statements from teachers involved in film education (Litorowicz, Majewski, 2011).

25 See Silwon-Bublej, 2014.
} 


\section{Bibliography:}

A Framework for Film Education in Europe (2015), Paris, 23 June. http://www.bfi.org.uk/ screening-literacy-film-education-europe.

Barczyk, A., Wierzejska O. Eódzcy studenci filmoznawstwa po zajęciach. Edukacja filmowa. http://www.edukacjafilmowa.pl/dla-szkoly/dobre-praktyki-edukacyjne/item/2021 (access: 16.08.2016).

Blicharska F. (1975). Film, [in:] F. Blicharska (ed.), Literatura a plastyka, muzyka, radio i film na lekcjach jezzyka polskiego. Warszawa: Wydawnictwa Szkolne i Pedagogiczne.

Bobiński, W. (2001). Teksty w kulturze ekranu. Okotofilmowa strategia ksztatcenia literackokulturowego. Kraków: Universitas.

Ciszewska, E. (2016). “Jeszcze nie przełom. Łódzkie tradycje edukacji filmowej.” Kino, no. 3.

Depta, H. (1975). Film i wychowanie. Warszawa: Wydawnictwa Szkolne i Pedagogiczne.

Depta, H. (1983). Film w życiu i wychowaniu mtodzieży. Warszawa: Wydawnictwa Uniwersytetu Warszawskiego.

Druick, Z. (2011). UNESCO, Film and Education. Mediating Postwar Paradigms of Communication, [in:] Ch. R. Acland, H. Wasson (eds.), Useful Cinema. Durham-London: Duke University Press.

Dvořáková, T. Cz. (comp.), Komentovaná literatura, http://filmvychova.cz/cz/metodika/ komentovana-literatura/ (access: 25.07.2016).

Faure, G. (ed.) (1972). Learning to Be. The World of Education Today and Tomorrow. Paris: UNESCO.

Filmoteka Szkolna (2016). http://filmotekaszkolna.pl/aktualnosc,1132 (access: 11.07.2016).

Frycie, S., Koblewska, J. (eds.) (1979). Film na lekcjach jezzyka polskiego. Warszawa: Wydawnictwa Szkolne i Pedagogiczne.

Gajda, J. (1982). Telewizja a upowszechnianie kultury. Warszawa: Instytut Wydawniczy Związków Zawodowych.

Gajda, J. (1987). Telewizja, mtodzież, kultura. Warszawa: Wydawnictwa Szkolne i Pedagogiczne.

Gajda, J. (1979). Telewizja w ksztatceniu kultury literackiej uczniów. Warszawa: Wydawnictwa Szkolne i Pedagogiczne.

Grawon-Jaksik, A., Materska-Samek, M. (eds.) (2016). Czy kinematografia kręci się wokót dzieci? Kondycja kinematografii dla dzieci i analiza uwarunkowań edukacji filmowej dzieci do 12 roku życia. Kraków: Fundacja Rozwoju Kina.

Górecki, M., Sotomska, A. (eds.). Film Literacy Initatives. http://kreatywna-europa.eu/wpcontent/uploads/2016/01/Film-Literacy-Initiatives-2014-1.pdf (access: 16.08.2016).

Hendrykowski, M. (ed.) (1997). Poloniści o filmie. Poznań: WiS.

Imre, A. (2016). TV Socialism. Durham-London: Duke University Press.

Jajko, K. (2016). “W drodze. Kino objazdowe PRL-u.” Ekrany, no. 1.

Kinonh.pl. http://www.kinonh.pl/pliki/HISZPANKA_scenariusze_lekcji.pdf., (access: 16.08.2016).

Klejsa, K. (2016). “Profesor Ewelina Nurczyńska-Fidelska (1938-2016). Wspomnienie. Pleograf." Kwartalnik Akademii Polskiego Filmu, no. 1. http://akademiapolskiegofilmu.pl/pl/ historia-polskiego-filmu/pleograf/andrzej-wajda/1/profesor-ewelina-nurczynska-fidelska-19382016-wspomnienie/544 (access: 4.07.2016). 
Koalicja filmowa. www.koalicjafilmowa.pl (access: 20.09.2016).

Koblewska, J., Butkiewicz, M. (eds.) (1985). Edukacja filmowa w szkole podstawowej i średniej. Warszawa: Wydawnictwa Szkolne i Pedagogiczne.

Koblewska, J. (1976). Wspótczesne modele edukacji filmowej na świecie, [w:] J. Masłowska (ed.), Modele edukacji filmowej. Warszawa: Wydawnictwa Centralnego Ośrodka Metodyki Upowszechniania Kultury.

Koblewska-Wróblowa, J. (1961). Film i dzieci. Warszawa: Wydawnictwa Artystyczne i Filmowe. Koblewska-Wróblowa, J. (1964). Film fabularny w szkole. Warszawa: Państwowe Zakłady Wydawnictw Szkolnych.

Korsak, Z. (2004). Kultura filmowa-edukacja filmowa. Koncepcje, badania, uwarunkowania. Włocławek: Wydawnictwo Akademii Humanistyczno-Ekonomicznej.

Kulik, A. (1964). Upodobania filmowe dzieci. Warszawa: Wydawnictwa Uniwersytetu Warszawskiego.

Lambert Peters, J. M. (1965). Edukacja filmowa (transl. Stanisława Dłuska). Warszawa: Wydawnictwa Artystyczne i Filmowe.

Lewicki, B. W. (1995). Mtodzież przed ekranem, [in:] Lewicki, B. W. O filmie. Wybór pism. E. Nurczyńska-Fidelska, B. Stolarska (eds.). Łódź: Wydawnictwo Uniwersytetu Łódzkiego.

Litorowicz, A., Majewski, P. (2011). Raport: Edukacja filmowa w polskiej szkole na podstawie opinii nauczycieli uczestniczacych w warsztatach "Filmoteki szkolnej". Warszawa. http://www. koalicjafilmowa.pl (access: 16.08.2016).

Machwitz, Z. (2007). Dom Kultury Filmowej. Łódź: Łódzki Dom Kultury.

Marzec, A. (1990). Edukacja filmowa w szkole średniej. Kraków: Centrum Doskonalenia Nauczycieli Oddział w Krakowie.

Miller, E. (1980). Doświadczenia Eódzkiego Domu Kultury w upowszechnianiu filmu w'środowiskach mtodzieżowych, [in:] J. Rulka (ed.), Problemy kultury filmowej. Materiaty z konferencji naukowej. Bydgoszcz: Wydawnictwo Uczelniane WSP Bydgoszcz.

Moraczewski, K. (2003). "Wokół przedmiotu wiedza o kulturze.” Kultura Wspótczesna, no. 3.

Nurczyńska-Fidelska, E. (1989). Edukacja filmowa na tle kultury literackiej. Łódź: Wydawnictwo Uniwersytetu Łódzkiego.

Nurczyńska-Fidelska, E. (2002). Edukacja kulturalna, [in:] S. Bednarek, A. J. Omelaniuk, A. Tyszka, A. Zieliński (eds.), Kongres Kultury Polskiej 2000. Wrocław-Warszawa: Wydawnictwo Dolnośląskie Towarzystwo Społeczno-Kulturalne Silesia.

Nurczyńska-Fidelska, E., Parniewska, B., Popiel-Popiołek, E., Ulińska, H. (1993). Film w szkolnej edukacji humanistycznej. Warszawa-Łódź: Wydawnictwo Naukowe PWN.

Piątkowski, B. (1975). Jarmark X Muzy. Film polski w latach 1900-1945. Łódź: Wydawnictwo Łódzkie.

Silwon-Bublej, U. (2014). Programy edukacyjne Sieci Kin Studyjnych i Lokalnych Filmoteki Narodowej, [in:] D. Górecka, D. Gołębiowska (eds.), Edukacja filmowa na zajęciach szkolnych i pozaszkolnych. Poradnik dla dyrektorów placówek oświatowych, nauczycieli, wychowawców, edukatorów filmowych. Warszawa: Filmoteka Narodowa, Polski Instytut Sztuki Filmowej, Sieć Kin Studyjnych i Lokalnych.

Skoczylas, L. (1975). Jak kinoteatr wychowuje nasza mtodzież?, [in:] J. Bocheńska (ed.), Polska myśl filmowa. Antologia tekstów z lat 1898-1939. Wrocław-Warszawa-Kraków-Gdańsk: Ossolineum.

Stylowy.net. http://www.stylowy.net/data/edu/0/37.pdf, (access: 16.08.2016). 
Szlązakowa, A. (ed.) (1967). Środki techniczne w nauczaniu języka polskiego w szkole średniej. Warszawa: Państwowe Zakłady Wydawnictw Szkolnych.

Świderska-Chorąży, E. (2011). Bliżej kina. Konferencje filmoznawczo-metodyczne w Borkach. Warszawa: Zakład Graficzny Uniwersytetu Warszawskiego.

Trebišovský, J. V., Lehuta, E., Hapala, D., Zachar, J. (1969). Základy filmovej výchovy. Príručka pre učitelov slovenského jazyka a literatúry v školách I a II cyklu. Bratislava: Slovenské pedagogické nakladatel'stvo.

Zespół Centralnego Gabinetu Edukacji Filmowej w Łodzi (eds.) (2015). 25 lat Ogólnopolskich Konferencji Filmoznawczych Borki-Radziejowice 1991-2015. Łódź: Centralny Gabinet Metodyczny Edukacji Filmowej Dzieci i Młodzieży.

\section{Summary}

The text explores traditions of film education, understood as education through film, in Polish film studies. Although film education has been a de facto part of informal education, we can trace many initiatives aimed at making it an element of formal schooling. Hence the attempt to incorporate film education into school curriculums at various levels of education, undertaken mainly by academic film experts (B. W. Lewicki, E. Nurczyńska-Fidelska). School film education has been fraught with numerous technological obstacles, as well as a lack of available materials to use as a foundation for educational practice. It has also been a challenge to develop appropriate competences of teaching staff. Film education has not found its place as a subject within formal education until today. The current fragmentation of entities responsible for it, and the lack of a coherent strategy means that film education becomes the domain of commercial and non-commercial programmes implemented in cinemas for the purposes of school education.

Keywords: film literacy, film education 